\title{
MORPHOLOGICAL CHARACTERISTICS OF HEPATOTOXIC EFFECTS OF STABLE STRONTIUM CHLORIDE IN CHRONIC EXPERIMENTS IN RATS
}

\section{Lugovskyi S. P.', Shlopov V. G. ${ }^{2}$, Sudya D. A. ${ }^{3}$}

\author{
ISI «Institute for Occupational Health of NAMS of Ukraine», Kiev \\ 2Donetsk National Medical University \\ ${ }^{3}$ Odessa National Medical University
}

\begin{abstract}
Background. In recent years, stable strontium and its compounds have found their wide application in various branches such as industry, agriculture, medicine, as well as in everyday life. However, aspects of the toxic effects of metal and its compounds
\end{abstract} on the body are not yet fully understood.

Purpose of the study. To study hepatotoxicity effects of stable strontium chloride in chronic experiments in rats, according to morpho-functional data.

Materials and methods. An experimental model of chronic strontium intoxication was used on male rats $(\mathrm{n}=36)$, daily ( 5 days a week for 4 months) in intragastric gavages of an aqueous solution of strontium chloride in the stable dose of $1 / 30 \mathrm{DL}_{50}$. The hepatotoxic evaluation of stable strontium chloride effects was made according to histological and histochemical study on rat liver after 1, 2, 3 and 4 months. For this purpose histological specimens were stained with hematoxylin \& eosin, toluidine blue, ammoniac solution of silver nitrate, mixture of sudan III \& IV. Histochemical reactions were carried out: PAS (periodic acid-Schiff) in combination with diastase (PAS-D stain) for detection of glycogen, as well as the coupling with naphthol AS- BS- phosphate for detecting the activity of acid phosphatase (AP).

Results. The studies have shown that chronic exposure to low doses of stable strontium chloride, are accompanied by development of hepatotoxic effects, which are characterized by: blood circulation impairment (blood stasis in hepatic veins and sinusoidal capillaries, especially in hepatic acini zone III); stromal edema and organ hyalinosis with collagen fibers; lipo- and protein dystrophy of hepatocytes, developed due to the reduced amount of glycogen in hepatocytes; hypertrophy and hyperplasia of Kupffer cells, as well as the increase in the amount of Kupffer cells in hepatocytes, due to histochemical activity of AP.

Conclusion. Chronic exposures to stable strontium chloride in small doses, at $1 / 30 \mathrm{DL}_{50}$ causes development of drastic effects due to hepatotoxic metal action, which should be taken into consideration, when assessing the risk of exposure to this metal both for industrial and household environment.

Key words: stable strontium, intoxication, experiment, hepatotoxic effects

The development of modern industries is impossible without use of new and advanced materials, among which strontium takes a special place, being a soft, malleable and ductile alkaline earth metal, having silvery white color with high chemical activity. The United States, Japan, Germany, South Korea and China annually produce several hundred thousand tons of strontium carbonate compounds, which are used for production of special glass, needed for color television screens, monitors and other display production. Thus, for production of each color television screen or monitor $1 \mathrm{~kg}$ of strontium oxide is used on the average. Tens additives of thousand tons of strontium are used in production of high-quality ferrites (ceramic magnets) and multilayer ceramic capacitors [1]. Strontium increases the hardness of aluminum and copper, corrosion resistance of zinc, aluminum and aircraft magnesium alloys, and that is why strontium is widely used in the modern high-tech [2]. In addition, strontium compounds are used for manufacturing various ceramic glazes and paints. Earlier, lead compounds were used for this purpose. Also it should be noted that significant amounts of strontium is contained in raw phosphogypsum, which is used in large quantities for production of phosphate fertilizers [3]. The use of strontium compounds is not limited by high-tech industries. In recent years, various strontium compounds are widely used in medicine and household. Strontium chloride is an important component in production of toothpastes and various types of cosmetics. Strontium ranelate is used in modern medicine for prevention and treatment of osteoporosis [4]. The toxic properties of various strontium compounds are summarized in a number of studies [5]. It is shown that stable strontium compounds are virtually chemically identical to 
radioactive metal compounds, and this is very important from the evaluating point of view of metal toxic properties.

Purpose of the study: To study hepatotoxicity effects of stable strontium chloride in rat's liver in its chronic effects on the body, according to morphological and functional data.

\section{Materials and methods}

Experiments were carried out on 36 conventional, randomized, outbreed adult male albino rats category II, weighing 120-130 g, which were kept under standard vivarium conditions in standard mode; food and free access to water, which was precipitated for at least 24 hours, were given. All rats were divided into two groups, experimental and the control. In the test group we used 24 rats, 6 in each of 4 groups, and in the control group - 12 rats, respectively. All experiments were performed in compliance with all basic requirements and recommendations of the European Convention for humane treatment of vertebrate animals, used for experimental purposes [6]. Experimental intoxication with stable strontium chloride was reproduced daily ( 5 days per week for 4 months) intragastric, by gavages $1,0 \mathrm{ml}$ injection a stable aqueous solution of strontium chloride in the dose of $60,0 \mathrm{mg} / \mathrm{kg}$ (a dose correspondes to $1 / 30$ DL50). The control rats were treated in a similar manner and aqueous solution of $0,9 \%$ sodium chloride was inserted. Experimental animals were taken out after 1, 2, 3 and 4 months by decapitation after anesthesia with thiopental sodium provision (40,0 mg $/ \mathrm{kg})$. For morphological studies pieces from the large lobe of the liver were taken (dimensions $1 \times 1 \times 0,5 \mathrm{~cm}$ ) and then were fixed for $24-48 \mathrm{~h}$ in $10 \%$ neutral formalin solution and calcium-formol, later frozen in dry ice-cooled petroleum ether. The fixed slices were washed with water, dehydrated in ethanol solution, increasing the concentration of antireflection in xylene and embedded in paraffin. Paraffin microtome slides of $7-10$ microns were stained with hematoxylin and $\operatorname{Eosin}(\mathrm{H} \& \mathrm{E})$, toluidine blue solution ( $\mathrm{pH} \mathrm{2,8)} \mathrm{for} \mathrm{detection} \mathrm{of} \mathrm{neutral} \mathrm{and}$ acidic glycosaminoglycans, ammoniac solution of silver nitrate for detecting reticular fibers and Schiff's reagent in combination with diastase (PAS-D stain) for glycogen detection [7]. Sections were prepared from frozen liver slices with cryostat, 10-15 microns thickness and used for histochemical reaction by diazotization with naphthol AS- BS- phosphate (a method of Goldberg and Barka) [8] for activity detection of acid phosphatase (AP) and staining with a mixture of lipids sudan III \& IV. Histological and histochemical preparations were examined under a light microscope «Olimpus BX 54». All observed changes were grouped by separate sings in order to assess their severity in each chronic experiment term. Then the frequency of occurrence of each of these 10 fields of each drug was counted. The results are expressed in relative units (\%). A statistical analysis was performed by Fisher's F-test under the null hypothesis, [9] the numerical data obtained was converted into the empirical value $\phi_{\text {empir }}$ (the statement of normal distribution of frequency characteristics), which compared with its critical value $\left(\phi_{\text {krit }}-1,64\right)$. When $\phi_{\text {empir }} \leq \phi_{\text {krit }}$ the hypothesis of inequality was rejected, when $\phi_{\text {empir }} \geq 1,64$ statistically significant differences were assessed at the level of $\phi=0,05\left(p_{u}<0,05\right)$, changes were those that satisfy the conditions $\phi_{\text {empir }} \geq 1,64$.

\section{Results and discussion}

The results of histological studies have shown that chronic exposure to stable strontium chloride in the experiment is characterized by development of plethora in interlobular and terminal hepatic veins, sinusoidal expansion of capillaries and blood stasis in the microcirculatory vessels of the hepatic acyni 3 -rd zone, in the early stages of the experiment ( $1-2$ months), accompanied by edema, swelling and disorganization of collagen fibers, and at a later stage (3-4 months) - hyalinosis of collagen fibers. At the same time hyperplasia and hypertrophy of stellate macrophages (Kupffer cells) were found in the liver at all stages of experiment, when compared with the control group, as well as the development of degenerative changes of hepatocytes, which in the early stages of experience (1-2 months) were characterized by edema of the nuclei and cytoplasm, and at the later stage (3-4 months) by a fine-grained nature of their cytoplasm and infiltration of the cytoplasm with small inclusions of lipids and hyaline masses (Fig. 1).

Histochemical studies have shown that hepatocytes develop degenerative changes due to lower amounts of glycogen in the cells and increasing the activity of the enzyme AP (Fig. 2, 3). In addition, these changes involved hepatocytes, arranged in central zones of the 
hepatic lobes. The increase in enzyme activity was detected in AP hypertrophic Kupffer cells, which was a testament to their high functional activity. It is known that the activity of AP is a histochemical marker of lysosomes, involved in providing a number of important cell functions, associated not only with the absorption of its various components, but, also, with their metabolic conversion, biodegradation and elimination from cells to the outside environment.

The evaluation of morphological changes in the liver, according to the analysis, conducted by the detection rate of morphological evidence, presented as normal distribution $(\phi)$, has identified features of hepatotoxic effects in the dynamics of chronic intoxication by strontium. It has been shown that at early stages of the intoxication circulatory disorders in the liver were dominating. For example, after 1 month of the metal influence on the body, enhanced fullblooded hepatic veins and sinusoidal capillaries of the hepatic acinus 3-rd zone were seen in much higher frequency. By the end of the experiment ( 4 months) the frequency of these changes significantly decreased
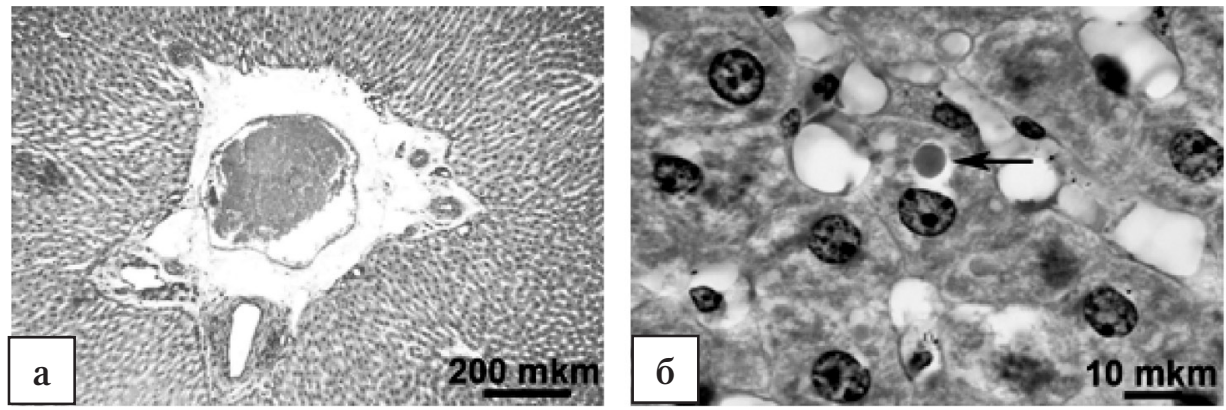

Fig. 1. Histological changes in the liver of rats after chronic exposure to stable strontium chloride:

a) -1 month experiment. Venous congestion and edema of the stroma; $b)-4$ months experiment.

Expansion of the sinusoidal capillaries and hyaline dystrophy of hepatocytes $(\leftarrow)$. Hematoxylin \& eosin
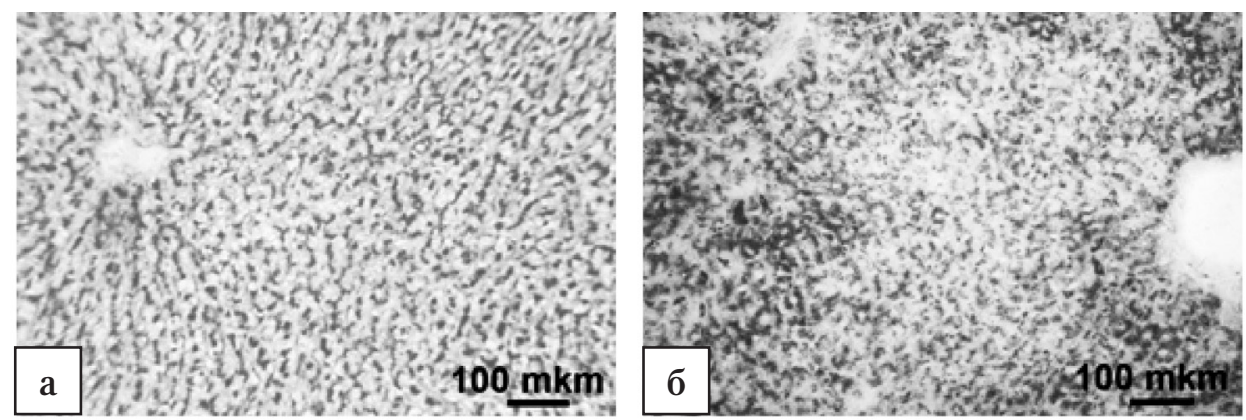

Fig. 2. FFig. 2. Histochemical acid phosphatase reaction in rat's liver: a) - control; b) - 3 months intoxication with stable strontium chloride. The histochemical reaction by diazotization with naphthol AS-BS-

phosphate (method of Goldberg and Barka)
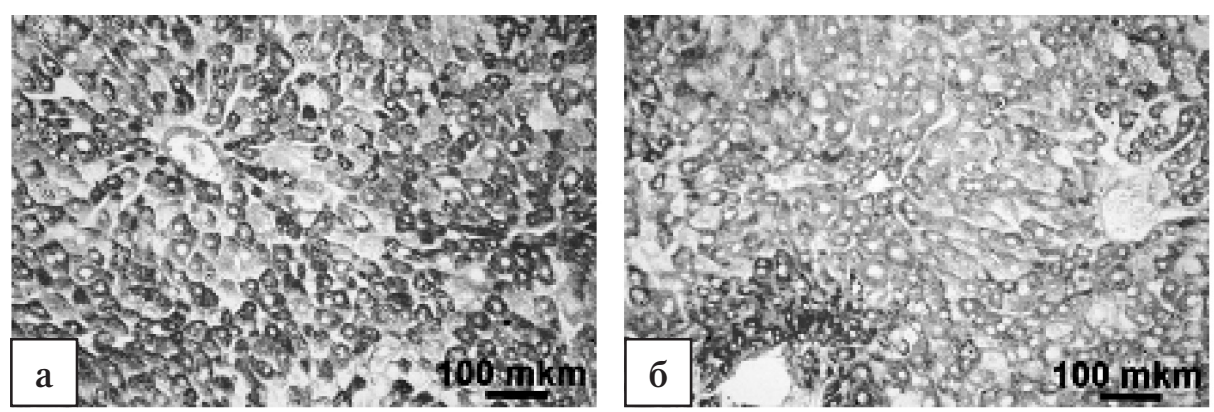

Fig. 3. Histochemical reaction for glycogen in rat's liver: a) - control; b) - 3 months intoxication with stable strontium chloride. PAS-D stain 
$\left(p_{u}<0,05\right.$, Table $)$. At the same time the stasis of blood frequency indicator in capillaries showed undulating natural changes. At the beginning of the experiment ( 1 month) it was high, then, after the 2-nd and 3-rd months of intoxication it increased and again decreased significantly by the end of the experiment ( 4 month), significantly higher than the level at the initial period of the experiment $\left(\mathrm{p}_{\mathrm{u}}<0,05\right.$, Table). If we consider that the determining factor in the development of blood stasis in the capillaries is a factor of membranes rupture of red blood cells, circulating in the blood [10], it should be thought that after 2 -nd and 3 -rd months of the experiment compensatory and adaptive changes develop in rats, supporting the structural integrity of red blood cells [11]. At the same time at the end of the experiment (after 4 months) the depletion of compensatory mechanisms, which supports partially lost body functions, leads to development of disorders in the body microcirculation.

During chronic exposure to stable strontium a connective stroma body edema was revealed, maximum manifestation was at the initial steps of the experiment (1-st and 2-nd months.). Later, in the course of the experiment, on the 3-rd and 4-th months, the frequency of such changes significantly was reduced $\left(\mathrm{p}_{\mathrm{u}}<0,05\right.$, Table). On the other hand, the frequency of edema, swelling and disorganization of collagen fibers increased. Furthermore, towards the end of the experiment the detection of collagen fiber hyalinosis significantly increased (pu 0,05, Table), clearly indicating development of mesenchymal dystrophy in the liver. In the liver parenchyma under the influence of stable strontium chloride there was evidence of nuclei and cytoplasm edema of hepatocytes, whose frequency was significantly reduced by the 3 -rd and 4 -th months of the exposure, in comparison with the initial period of the experiment $\left(\mathrm{p}_{\mathrm{u}}<0,05\right.$, Table $)$. At the same time lipodystrophy was developed in the liver, the maximum severity of which was reached by the 3 -rd and 4 -th months of the experiment (Table). Protein dystrophy of hepatocytes was present as well. In this case, lipodystrophy and protein dystrophy of hepatocytes developed due to granular dystrophy progression, and further reduction of glycogen amount in the cells (Table).

It should be noted that the development of degenerative changes in the dynamics of chronic stable strontium chloride influence is accompanied by hypertrophy and hyperplasia of Kupffer cells, as well as by increasing of AP histochemical enzyme activity in the hepatocytes (Fig. 2, Table).

The results of our morphological studies so far, correspond to the same reported sources in literature [12], in which the authors discuss changes in the liver, in the acute and subchronic experiments discovered by them, characterized by disorders of blood circulation in the microvascular system, as well as by degenerative and necrotic changes of

Comparative evaluation of morphological changes in the liver of rats after chronic exposure to stable strontium chloride, $\phi-$ the statement of the normal distribution frequency of revealed characteristics

\begin{tabular}{|l|c|c|c|c|}
\hline \multirow{2}{*}{ Morphological changes (signs) } & \multicolumn{4}{c|}{ Groups } \\
\cline { 2 - 5 } & $\mathbf{1}(\mathbf{n}=\mathbf{6})$ & $\mathbf{2}(\mathbf{n}=\mathbf{6})$ & $\mathbf{3}(\mathbf{n}=\mathbf{6})$ & $\mathbf{4}(\mathbf{n}=\mathbf{6})$ \\
\hline Lumen expansion \& vascular congestion & 1,266 & $0,959^{*}$ & $0,876^{*}$ & $0,795^{* \#}$ \\
\hline Sinusoidal expansion \& capillary congestion & 1,328 & $0,940^{*}$ & $0,927^{*}$ & $0,823^{*}$ \\
\hline Capillary blood stasis & 1,328 & $0,795^{*}$ & $0,940^{* \#}$ & $1,611^{* * \#}$ \\
\hline Stromal edema & 1,093 & 1,182 & $0,809^{* \#}$ & $0,879^{* \#}$ \\
\hline Edema, swelling and disorganization of collagen fibers & 0,423 & 0,451 & $0,952^{* \#}$ & $1,341^{* \#+}$ \\
\hline Collagen fiber hyalinosis & 0,190 & $0,927^{*}$ & $1,174^{* \#}$ & $1,772^{* \#+}$ \\
\hline Hypertrophy and hyperplasia of Kupffer cells & 1,308 & 1,318 & 1,479 & $1,621^{* \#+}$ \\
\hline Cytoplasm and nuclei of hepatocytes edema & 1,077 & 0,957 & $0,876^{*}$ & $0,823^{*}$ \\
\hline Hepatocyte granular degeneration & 0,957 & 1,070 & 1,124 & $1,224^{*}$ \\
\hline Hepatocyte lipodystrophy & 0,516 & $0,981^{*}$ & $1,056^{*}$ & $1,024^{*}$ \\
\hline Hepatocyte hyaline dystrophy & $\mathrm{n} / \mathrm{a}$ & $\mathrm{n} / \mathrm{a}$ & 0,318 & 0,473 \\
\hline Glycogen reducing in Hepatocytes & 0,881 & $1,070^{*}$ & $1,115^{*}$ & $1,249^{* \#}$ \\
\hline Acid phosphatase activity increase in hepatocytes & 1,245 & 1,211 & 1,297 & $1,611^{* \#}$ \\
\hline
\end{tabular}

Statistically significant at $\alpha=0,05$, compared with groups: ${ }^{*} 1 ;{ }^{*} 2 ;{ }^{\dagger} 3$. 
hepatocytes. The authors note the development of not only parenchymal, but, also, mesenchymal dystrophy of hepatocytes, which are manifested in the form of fibrous connective tissue plasmorrhagia. It should be also noted that our histochemical studies indicate the leading role of carbohydrate, lipid and protein metabolism in the development of hepatotoxic effects of stable strontium compounds, as well as not enough estimated role of lysosomes and their hydrolytic enzymes, ensuring the protection and, on the other hand, liver cell damage under the influence of stable strontium on the body. Certain aspects of the role of lysosomes in mechanisms of protection and cell damages in exposures to heavy metals are widely discussed in the literature on the pages of modern scientific publications [13].

\section{References}

1. http://www.inchem.org/documents/cicads/ cicads/cicad77.pdf., 2010, IPCS. Strontium and strontium compounds: Concise International Chemical Assessment Document 77. WHO, Geneva.

2. Nokhrina, O. I., Rozhihina, I. D., Dmitrieynko, V. I., Platonov, M. A. 2012, "Doping and modifying steel with natural materials", Tomsky Polytechnical University: Tomsk, 320 p. (in Russian).

3. Petrenko, D. V. 2014, «Effect of phosphate fertilizer on the content of strontium in landscapes" (Dissertation). Moscow, 159 p. (in Russian).

4. Reginster, J. Y. 2002, "Strontium ranelate in osteoporosis", Curr. Pharm. Des., no. 8, pp. 1907-1916.

5. Sudya, D. A. 2013, "Problems of toxic influence of stable strontium salts on the body (review)", Modern problems of toxicology, food and chemical safety, no. 3, pp. 55-60 (in Russian).

6. European Convention for the protection of vertebrate animals, used for experimental and other scientific purposes, 1986, Strasbourg: Council of Europe, 53 p.

7. Microscopic technique (Manual). 1996, (Ed. D. S. Sarkisov and Yu. Perov). Moscow: Meditsina, 544 p. (in Russian).

\section{Conclusions}

Histological and histochemical studies on rat liver revealed hepatotoxic effects in chronic exposures of the body to stable strontium chloride at the dose of $1 / 30 \mathrm{DL}_{50}$. Among the most characteristic morphological signs of stable strontium chloride hepatotoxicity are: circulatory disorders in hepatic veins plethora and sinusoidal capillaries, mostly in the 3 -rd zone of the hepatic acini; edematous stroma changes with development of collagen fibers hyalinosis; development of lipodystrophy and protein dystrophy in hepatocytes, due to lower amount of glycogen in cells, Kupffer cell's hypertrophy and hyperplasia, and the increase in alkaline phosphatase liver enzyme histochemical activity.

8. Lloyda, H., Gossrau, R., Shibler, T. 1982, «Enzymes histochemistry. Laboratory methods" (translated from English by I.B. Bukhvalova and others), Ed. N. T. Raichlin. Moscow : Mir, 270 p. (in Russian).

9. Gubler, E. V. 1978, Computational methods of analysis and detection of pathological processes. Leningrad : Meditsina, 296 p. (in Russian).

10. Ryazantseva, N. V., Novitsky, V. V., Stepovaya, E. A., Tkachenko, S. B. 2004, "Erythrocytes in pathology: Reflections from an electron microscope", Archives of Pathology, no. 3, pp. 53-61 (in Russian).

11. Aruin, L. I., Babayev, B., Gelfand, V. B. et al. 1987, Basic structure of adaptation and compensation of disturbed functions (Eds. D.S. Sarkisov). Moscow : Meditsina, 448 p. (in Russian).

12. Zyuzyukin, Y. 1976, "To the problem on toxic properties of strontium in inhalations", Gigiyena i sanitaria, no. 8, pp. 99-100 (in Russian).

13. Shafran, L. M., Large, D. V., Pykhteyeva, E. G., et al. 2004, "The role of lysosomes in the mechanism of protection and cell damage under the influence of heavy metals", Modern problems of toxicology, no. 3, pp. 17-24 (in Russian).

\section{^уговсыкий С. П.', ШАопов В. Г.' ${ }^{2}$, СуААя А. О. ${ }^{3}$ MOРФОЛОГІЧНА ХАРАКТЕРИСТИКА ГЕПАТОТОКСИЧНИХ ЕФЕКТІВ ХАОРИАУ СТАБІАЬНОГО СТРОНШЮ ПРИ ХРОНІЧНОМУ ВПАИВІ НА ШУРІВ}

\section{'АУ «Інститут меАишини праші НАМН України», М. Київ ${ }^{2} \Delta$ онешький нашіональний меАичний університет

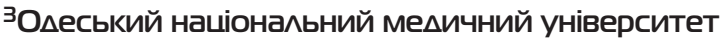

Bcmyn. Останніми роками стабільний хлорид стронцію та його сполуки знайшли своє широке використання в різних галузях промисловості, сільському господарстві, медицині та побуті. Проте аспекти токсичної дії металу та його сполук на організм залишаються в повній мірі не вивченими. 
Мета дослідження. Вивчити за даними морфо-функціонального дослідження печінки щурів ефекти гепатотоксичної дії хлориду стабільного стронцію при хронічному впливі на організм.

Матеріали та методи дослідження. Експериментальну модель хронічної інтоксикації стронцієм відтворювали на шурах-самцях ( $\mathrm{n}=36)$ шляхом щоденного (5 днів на 1 тиждень впродовж 4 місяців) внутрішньошлункового введення через зонд водного розчину хлориду стабільного стронцію в дозі 1/30 ЛД 50 . Оцінку гепатотоксичних ефектів хлориду стабільного стронцію проводили за даними гістологічних і гістохімічних досліджень печінки щурів через 1, 2, 3 і 4 місяців. Для цього гістологічні препарати забарвлювали гематоксиліном і еозином, сумішшю судану III і IV, а також проводили гістохімічні реакції ШИК-йодна кислота (метод Шабадаша) для виявлення глікогену та азосполучення з нафтолом AS- BS- фосфатом (метод Goldberg i Barka) для виявлення активності ферменту кислої фосфатази (КФ). Результати. Проведені дослідження показали, що хронічний вплив малих доз хлориду стабільного стронцію супроводжується розвитком гепатотоксичних ефектів, які характеризуються порушенням кровообігу (повнокров'я печінкових вен і синусоїдальних капілярів, переважно III зони печінкових ацинусів), набряком строми органа й гіалінозом колагенових волокон, дрібнокапельною жировою та білковою гіаліново-крапельною дистрофією гепатоцитів, що розвивається на фоні зниження кількості глікогену в гепатоцитах, гіпертрофією та гіперплазією клітин Купфера, а також збільшенням в гепатоцитах і клітинах Купфера гістохімічної активності КФ.

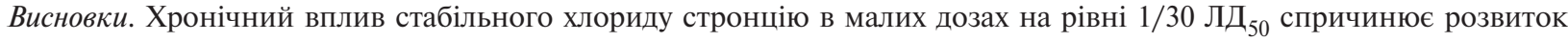
виражених ефектів гепатотоксичної дії металу, що завжди необхідно враховувати при проведенні оцінки ризику впливу металу в умовах виробництва та побуті.

Ключові слова: стабільний стронцій, інтоксикація, експеримент, гепатотоксична дія

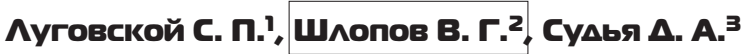 МОРФОЛОГИЧЕСКАЯ ХАРАКТЕРИСТИКА ГЕПАТОТОКСИЧЕСКИХ ЭФФЕКТОВ ХАОРИАА СТАБИМЬНОГО СТРОНЧИЯ ПРИ ЕГО ХРОНИЧЕСКОМ ВОВАЕЙСТВИИ НА КРЫС
}

\author{
'ГУ «Институт медишины труда НАМН Украины», г. Киев \\ ${ }^{2} \Delta$ онешкий нашиональный меАишинский университет

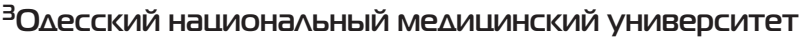

Вступление. В последние годы стабильный стронций и его соединения нашли свое широкое применение в различных отраслях промышленности, сельском хозяйстве, медицине, а также в быту. Вместе с тем аспекты токсического действия металла и его соединений на организм остаются в полной мере не изученными.

Цель исследования. Изучить по данным морфо-функционального исследования печени крыс эффекты гепатотоксического действия хлорида стабильного стронция при хроническом воздействии на организм.

Материалы и методы исследования. Экспериментальную модель хронической стронциевой интоксикации воспроизводили на крысах-самцах ( $\mathrm{n}=36)$ путем ежедневного (5 дней в 1 неделю в течение 4 месяцев) внутрижелудочного введения через зонд водного раствора хлорида стабильного стронция в дозе 1/30 ЛД 50 . Оценку гепатотоксических эффектов хлорида стабильного стронция проводили по данным гистологических и гистохимических исследований печени крыс через 1, 2, 3 и 4 месяцев. Для этого гистологические препараты окрашивали гематоксилином и эозином, толуидиновым синим, аммиачным раствором нитрата серебра, смесью суданов III и IV, а также проводили гистохимические реакции ШИК-йодная кислота (метод Шабадаша) для обнаружения гликогена и азосочетания с нафтолом AS- BS- фосфатом (метод Goldberg и Barka) для обнаружения активности фермента кислой фосфатазы (КФ).

Результаты. Проведенные исследования показали, что хроническое воздействие малых доз хлорида стабильного стронция сопровождается развитием гепатотоксических эффектов, которые характеризуются нарушением кровообращения (полнокровие печеночных вен и синусоидальных капилляров, преимущественно III зоны печеночных ацинусов), отеком стромы органа и гиалинозом коллагеновых волокон, мелкокапельной жировой и белковой гиалиновокапельной дистрофией гепатоцитов, развивающейся на фоне снижения количества гликогена в гепатоцитах, гипертрофией и гиперплазией клеток Купфера, а также увеличением в гепатоцитах и клетках Купфера гистохимической активности КФ.

Bыводы. Хроническое воздействие стабильного хлорида стронция в малых дозах на уровне 1/30 ЛД витие выраженных эффектов гепатотоксического действия металла, что всегда необходимо учитывать при оценке риска воздействия металла в производственных условиях и быту.

Ключевые слова: стабильный стронций, интоксикация, эксперимент, гепатотоксическое действие

Надійшла: 25.05 .2015 p.

Контактна особа: Луговський Сергій Павлович, доктор медичних наук, лабораторія медико-біологічних критеріїв професійного впливу, ДУ «Інститут медицини праці НАМН України», буд. 75, вул. Саксаганського, м. Київ, 01033. Тел.: + 3804428919 10. Електронна пошта: lugsp61@gmail.com 